9. Lytvyn L. (2013). Menedzhment osvitnikh innovatsii: sutnist ta osoblyvosti

10. vprovadzhennia [Management of educational innovation: the essence and features of implementation]. Sotsialno-ekonomichni problemy i derzhava, Vyp. 1(8). P. 108-115.

11. Marchenko L. (2009). Upravlinnia innovatsiinoiu diialnistiu pedahohiv v

12. umovakh profilnykh zahalnoosvitnikh navchalnykh zakladiv []. Zbirnyk naukovykh prats Berdianskoho derzhavnoho pedahohichnoho universytetu : pedahohichni nauky. Berdiansk : BDPU, Vyp. 2, P. 248-250.

13. Romanovskyi O. (2010). Shliakhy vprovadzhennia innovatsii,

14. pidpryiemnytstva ta pidpryiemnytskoi osvity v systemi natsionalnoi osvity Ukrainy: Monohrafiia [Ways of introducing innovation, entrepreneurship and entrepreneurship education in the national education system of Ukraine : Monograph]. Vinnytsia : Nova knyha, $416 \mathrm{p}$.

\title{
Gonchar L. V. Innovative approaches in the professional training of future managers
}

The problem of forming the professional culture of the future manager is analyzed in the article. The essence of the concepts of «innovation process», "educational innovation», "educational innovation process», "professional culture», "professional culture of the manager» from the point of view of different scientific approaches is revealed.

The author defines the concept of «educational innovation», which is considered as a complex, purposeful process of implementation, assimilation, use and dissemination in the educational activity of new ideas, orders, customs, methods, techniques, technologies, mechanisms, systems, structures, phenomena, etc., for the purpose ensuring its stability, improving efficiency and development in market conditions.

Levels of novelty: absolute novelty, locally absolute novelty, conditional novelty, subjective novelty are covered. The essence of educational innovations in forming the professional culture of future managers is characterized. Scientifically substantiated classification of educational innovation by: sphere of introduction is scientifically substantiated; the way of occurrence; the volume and depth of the innovation process; the basis on which they appear are innovations; the scale of conversions; innovative potential; depending on the position of its predecessor; places of origin; the level of expectations, forecasting and planning; areas of pedagogical knowledge, etc.

The components of pedagogical innovations in the formation of professional culture of future managers are distinguished. The most priority directions of training of managers with introduction of innovative technologies among them: module-development training, information and communication technologies, business, psycho-economic, intellectual trainings, business games, coaching trainings, brainstorming, games for teaming of non-standard teams conflict and critical situations are revealed.

Key words: educational innovation, future managers, professional culture, innovation.

УДК 376.1

DOI https://doi.org/10.31392/NPU-nc.series5.2019.71.18

Гончаренко О. В., Поляничко А. О.

\section{ГЕНДЕРНЕ ВИХОВАННЯ ХЛОПЦІВ ТА ШЛЯХИ ЙОГО ОПТИМІЗАЦІЇ}

Дослідження присвячене проблемі гендерного розвитку хлопиів та необхідності його оптимізації. Авторками аналізується зміст гендерної соціалізаџії в контексті традиційного (патріархального) та сучасного (альтернативного) виховання. У контексті вивчення традииійного підходу до виховання визначено, шо в його основу покладені жорстка гендерна диференціація чоловічого і жіночого та їх суворе ієрархічне розташування. Доведено, щзо такий підхід спирається на підкреслення відмінностей між чоловіками і жінками; орієнтачію на «особливе призначення» статей; закріплення у хлопчиків гендерно-стереотипних інтересів та уподобань; ігнорування індивідуальності та обмеження свободи вибору; виховання гендерно-схематизованих індивідів. Підгрунтям для особистісного розвитку хлопців слугує образ «справжнього чоловіка», який визначається нормами статусу, твердості (фізичної, розумової, емоційної) та антижіночності. Констатовано, щчо існуючі норми, правила поведінки, установки щзодо культурних уявлень про ролі, становище і призначення чоловіка в суспільстві, які покладені в основу традиційного виховання хлопчиків, в подальшому призводять до трудношів у дорослому житті.

У статті обтрунтовуються переваги особистісно-орієнтованої моделі виховання на основі гендерного підходу, який передбачає розвиток хлопиів поза жорсткими гендерними приписами та стереотипами. Авторки переконують, щзо сучасна соціалізація передбачає відсутність гендерної диференціаџіï та поляризаиії $і$ розглядається як процес засвоєння хлопчиками нових гендерних ролей, які з 'явилися у зв 'язку з інтенсивними соціокультурними змінами. Визначено, щзо в такій моделі виховання зростає роль сім'ї $і$ закладів освіти, які повинні стати активними суб 'єктами позитивних змін у процесі гендерного розвитку чоловічої молоді.

Ключові слова: гендерний підхід, традиційне і гендерне виховання, гендерні норми, особистісно-орієнтоване виховання.

Сучасний світ і життя в ньому настільки складні, багатогранні та мінливі, що треба бути готовим до всього. Процес особистісного розвитку сьогодні відбувається в ситуації набагато більшої, ніж раніше, соціальної варіативності і невизначеності видів діяльності, соціальних ролей та іншого. При цьому подібна різноманітність і динамічність суспільного життя все частіше вступають у протиріччя 3 тими традиційними (патріархальними за змістом) вимогами і приписами, які продовжують адресуватися жінкам і чоловікам. Отже, існуючі гендерні норми вже мало відповідають реальній дійсності. 
Науковці зауважують, що з кожним роком зростає кількість чоловіків, які виховують дітей без допомоги жінок, - так званих «моно батьків», які самостійно займаються домогосподарством, виступають у ролі чутливих і турботливих татусів. Так, за деякими даними, на зламі століть у США таких батьків нараховувалося близько 14 \%. Приблизно стільки ж родин з одним із батьків - татом - нині налічується і в нашій країні [6, с. 211].

Гендерологи стверджують, що переосмислення і напрацювання нових підходів у вихованні підростаючого покоління є затребуваними як ніколи, адже світ навколо нас змінюється із шаленою швидкістю. 3 кожним днем він стає набагато складнішим і багатшим за ті гендерні норми, що в своїй більшості виступають орієнтиром у педагогічній діяльності, обумовлюючи поширеність у суспільстві традиційного підходу до виховання дітей $з$ урахуванням статі. Тому закономірним постає питання про доцільність поширених у виховній практиці диференційованих за статтю підходів до виховання хлопчиків і дівчаток, розвитку в них різних (не індивідуальних, а статево специфічних) інтересів і здібностей, оріснтації на різні цінності та життєві задачі відповідно до реалій і нових викликів XXI століття.

Аналіз останніх досліджень і публікацій свідчить, що на сьогодні існує не так багато досліджень, присвячених вивченню специфіки гендерного розвитку представників чоловічої статі, адже більша увага науковців прикута до вивчення проблем жіночої гендерної ролі та їхнього низького соціального статусу. Окремі аспекти гендерної соціалізації хлопчиків висвітлюють у своїх роботах Ш. Берн, В. Гончаров, Ю. Гусєва, I. Жеребкіна, І. Захарова, Є. Ільїн, І. Кон, С. Оксамитна, Н. Радіна, Л. Семенова, М. Ткалич, А. Чекаліна та інші. Проте, останнім часом вивчення особливостей чоловічої ролі і гендерного виховання хлопчиків характеризується збільшенням інтересу з боку дослідників.

Мета статті - висвітлити особливості виховання хлопчиків із позиції традиційного й гендерного підходів; здійснити спробу переосмислити зміст гендерного розвитку хлопчиків відповідно до вимог сучасності та орієнтації на їхню індивідуальність як найвищу цінність виховного процесу.

Загалом гендерні ролі не виникають одразу з народженням дитини. Вони формуються в процесі гендерної соціалізації, залежать протягом життя від багатьох умов і чинників, адже від самого народження дитина потрапляє в соціальне оточення, яке задає безліч стереотипів статево-рольової поведінки. Зокрема, хлопчики змалку навчаються чоловічим моделям поведінки у суспільстві, засвоюють статево типізовані цінності, норми та інше. При цьому їхній гендерний розвиток має свою специфіку - закономірності, суперечності і навіть труднощі та обмеження, які накладають на них традиційні гендерні ролі. Від особливостей гендерного виховання хлопчика в дитинстві залежить характер життєвого сценарію дорослого чоловіка, його стиль життя та стратегії поведінки в різноманітних життєвих ситуаціях.

Вивчаючи проблему гендерного розвитку дітей, дослідники (Н. Радіна, С. Терешенкова та інші) акцентують увагу на тому, що зміст гендерного виховання може розглядатися за допомогою біполярного конструкта, 3 одного боку якого знаходиться «традиційна (патріархатна) соціалізація», іншого - «сучасна (альтернативна) соціалізація» [5, с. 49].

За твердженням Л. Штилевої, традиційне (або статево-рольове) виховання передбачає жорстку гендерну диференціацію чоловічого і жіночого, ієрархічно розташовані статуси чоловіків і жінок. Ця модель виховання спирається на такі принципи: підкреслювання відмінностей між чоловіками і жінками; орієнтація на «особливе призначення» статей і взаємодоповнюваність їхніх соціальних ролей; закріплення гендерно-стереотипних інтересів та уподобань; ігнорування індивідуальності особистості та обмеження свободи вибору, які «не відповідають» статевій приналежності; виховання гендерно-схематизованих індивідів [7, с. 146]. Прибічники цього підходу, переоцінюючи роль біологічних відмінностей між жінками і чоловіками в їхній соціальній поведінці та обгрунтовуючи зазначені принципи, як правило, посилаються на дані нейропсихології та психофізіології. При цьому, вони нерідко формулюють їх із відтінком упередженості.

3 огляду на основи статево-рольової соціалізації, вимоги до виховання чоловічої молоді виглядають наступним чином. Так, у межах традиційного підходу хлопчика орієнтують на презирливе ставлення до «жіночих слабкостей»; відмову від «жіночої роботи»; прагнення та вміння доводити свою силу і перевагу; вимоги щодо стримування від вияву емоцій; прагнення стати конкурентоспроможним професіоналом і заробляти гроші, набути реальної влади і високого статусу. Хлопців навчають бути сміливими, рішучими, наполегливими у досягненні поставленої мети, виявляти самостійність і принциповість, демонструвати свою силу і компетентність.

Отже, сучасних хлопців готують до життя в умовах жорсткої конкуренції і боротьби за олімпійською формулою «Швидше, вище, сильніше!», а в якості основних цінностей для них визначають професійний успіх і кар'єрні досягнення, необхідність постійно доводити свою перевагу. При цьому прагнення відповідати такому соціально сконструйованому ідеалу для хлопчика є не стільки внутрішньою потребою, скільки суспільною нормою. Іншими словами, підгрунтям їхнього розвитку слугує образ «справжнього чоловіка», який визначається нормою статусу, нормою твердості (фізичної, розумової, емоційної) і нормою антижіночності [2, с. 117]. Разом із цим хлопців зазвичай роблять безпомічними і безпорадними у побуті та самообслуговуванні, невідповідальними за тих, хто поруч з ними. В результаті охайність чоловіка, як це не дивно, стає обов'язком турботливої дружини. Натомість особистісний успіх виявляється єдиним сенсом життя більшості чоловіків, і вони йдуть до нього по головах інших, забуваючи заради кар'єри про власних дітей 
і нерідко жалкуючи про це у старості. Через гонитву за особистим успіхом в них відбуваються психосоматичні розлади та спостерігається відсутність спілкування з сім'єю. Проблеми зі здоров'ям виникають внаслідок чоловічих «розваг», ризикованого дозвілля та неконтрольованої поведінки.

Не оминає чоловіків і проблема дискримінації на робочому місці: по-перше, вони часто стають жертвами «скляного підвалу», оскільки їх кидають на найнебезпечніші роботи, що підвищує ризики нещасних випадків, травмування, втрати здоров’я і життя; по-друге, страх асоціації з жіночими видами діяльності породив ефект «скляного ескалатора», що змушує чоловіків «видиратися нагору» і займати такі посади, які вважаються гідними і престижними (наприклад, директор школи у фемінізованій освіті). Свої цілком вірогідні в наш час професійні невдачі чоловіки сприймають як катастрофу, що призводить до невпевненості, розчарування в житті та озлобленості, а в результаті - до алкоголізму, компенсаторного насилля і навіть самогубства.

Отже, наслідками традиційного виховання є поява наступних проблем у чоловіків:

1) безпомічність у побуті та самообслуговуванні;

2) безвідповідальність відносно оточуючих;

3) через гонитву за особистим успіхом відбуваються психосоматичні розлади, відсутність спілкування 3 сім'єю;

4) проблеми зі здоров'ям внаслідок чоловічих «розваг», ризикованого дозвілля та неконтрольованої поведінки;

5) дискримінація на робочому місці: чоловіки часто стають жертвами «скляного підвалу», оскільки їх кидають на найризикованіші та найнебезпечніші роботи, що підвищує ризики нещасних випадків: травмування, втрати здоров'я і життя;

6) страх асоціації з жіночими видами діяльності породив ефект «скляного ескалатора», що змушує чоловіків вибиратися нагору і займати такі посади, які вважаються достойними та престижними (наприклад, директор школи у фемінізованій освіті);

7) професійні невдачі - катастрофа, що призводить до невпевненості, розчарування в житті та озлобленості, а в підсумку - до алкоголізму, компенсаторного насильства, суїциду.

Таким чином, в умовах динамічного суспільства будь-які жорсткі стандарти і стереотипи поступово призводять до втрати здорового глузду. Крім цього, вони суттєво обмежують життєвий простір та особистісний потенціал людини (зокрема, чоловіків), накладаючи табу на інші альтернативні прояви індивідуальних якостей і здібностей.

На противагу зазначеному, фахівці все частіше констатують той факт, що успішна соціалізація передбачає не тільки засвоєння існуючих зразків поведінки, але й уміння протиставляти їм свої нормативи та еталони; не просто підкорення прийнятним правилам, а їхнє критичне і творче переосмислення [3, с. 116]. Тобто, сенс соціального розвитку особистості проявляється перш за все в індивідуальному розвитку. Сучасна соціалізація передбачає відсутність гендерної диференціації і поляризації; розглядається науковцями як процес засвоєння індивідом нових гендерних ролей, які з'явилися у зв'язку з інтенсивними соціокультурними змінами. Тому гендерне виховання і процес особистісного становлення хлопчиків потребують серйозного перегляду відповідно до вимог сучасності і орієнтацій на їхню індивідуальність як найвищу цінність виховного процесу.

На думку гендерологів (зокрема, В. Семенова та Л. Семенова), принцип демократизації і гуманізації передбачає особливу модель суспільства, що складається із різноманіття індивідуальностей, а не уніфікованих індивідів, яка визнається на сучасному етапі більш прогресивною і продуктивною. Така модель передбачає широке впровадження у практику особистісно-орієнтованого виховання, яке може базуватися на гендерному підході, в основі якого закладена повага прав кожної людини бути самою собою незалежно від своєї біологічної статі [6, с. 216].

За Л. Штилевою, основні принципи гендерного підходу у вихованні такі: відмова від диференціації за статтю у виховних впливах; нейтралізація та пом'якшення соціально обумовлених відмінностей між жінками і чоловіками; відсутність орієнтації на їхнє «особливе призначення» і визнання взаємозамінності жіночих і чоловічих соціальних ролей; реалізація ідей гендерної рівності; забезпечення кожній дитині свободи вибору, заохочення іiі індивідуальних інтересів і вподобань; створення умов для можливості бути різними хлопчиками і дівчатками; виховання гендерно-несхематизованих дітей [7, с. 167]. Відповідно до гендерного підходу, для якого особистість людини вища і важливіша за ії стать, передбачається, що зусилля дорослих та їхні виховні впливи будуть спрямовані у напрямі індивідуально-орієнтованого розвитку хлопчика поза жорсткими гендерними приписами та стереотипами, які роблять його заручником статі і обмежують активність межами «статево специфічних» вимог «можна» / «не можна».

В контексті зазначеного зростає роль батьків у вихованні хлопців. Сім'я, яка є основним агентом первинної соціалізації, є тим місцем, де закладаються основи виховання, в тому числі й погляди на роль чоловіків і жінок у суспільстві, демонструються домінаторні чи егалітарні засади взаємодії. Дослідження свідчать: якщо мама переконана у рівноправності гендерних ролей і вважає ідеальними жіночими якостями незалежність, самодостатність і свободу від зовнішнього контролю, то і син такої матері поділяє ці погляди щодо представниць протилежної статі. Виростаючи, такі чоловіки проявляють повагу до жінок, цінують їх особисту незалежність і дотримуються гуманістичних принципів. 
Надзвичайної важливості у вихованні сина набуває роль тата, від участі якого залежить формування гендерної ідентичності майбутнього чоловіка, адекватної високої самооцінки, самоповаги, позитивного самосприйняття, впевненості у собі й послідовності у своїх діях, оволодіння конструктивними засобами розв’ язання конфліктів. Зважаючи на досить суперечливий процес соціалізації хлопчиків у дитячому та підлітковому віці (зокрема, первинна ідентифікація хлопчика з матір'ю і тотальна фемінізація освітньої сфери на всіх іiі рівнях), присутність батька в житті сина стає справжнім взірцем маскулінності та адекватним образом для наслідування [4].

Не менш важливими у процесі гендерного виховання хлопців є сімейна атмосфера і батьківські взаємини. Розуміння між подружжям, підтримка, самореалізація, баланс сімейного та особистого, змістовне дозвілля, спільна участь у вихованні дітей, рівний розподіл домашньої роботи як компоненти гендерної рівності створюють сприятливе сімейне середовище для розвитку дитини, дотримання іiі прав, формування гармонійної особистості. Щаслива сім’я - найкращий життєвий сценарій і приклад для наслідування синами.

Шкільне середовище також є важливим фактором гендерної соціалізації хлопців. Значною стає роль соціального педагога, який повинен бути активним суб' єктом позитивних змін у процесі гендерного розвитку учнів, адже його робота спрямована на гуманізацію соціального середовища, профілактику конфліктів, покращення стосунків особистості і соціуму. Соціальний педагог покликаний допомогти хлопчикам шкільного віку адаптуватися до мінливих соціальних умов, обрати життєву стратегію відповідно до власних здібностей і прагнень, сприяти розвитку навичок творчого перетворення дійсності.

Для оптимізації виховної практики американською психологинею Сандрою Бем були розроблені рекомендації щодо виховання гендерно-несхематизованої дитини, які можна порадити використовувати як батькам, так і соціальним педагогам з метою подолання труднощів у процесі гендерної соціалізації хлопців. Така модель включає в себе такі дві стратегії:

1. Навчання хлопців справжнім відмінностям між статями, тобто біологічним визначенням статі, що означає:

1) ознайомлення хлопців з жіночою і чоловічою анатомією (як би це не було складно для дорослих і не викликало в них зніяковіння);

2) відміна від дисциплінування хлопців з вказівкою на їх статеву приналежність (наприклад, «Ти ж хлопчик, ти не повинен жалітися і рюмсати, як якесь дівчисько! Піди і дай здачі!»).

2. Надання хлопцям доступної для їх розуміння альтернативної інформації про стать, в якості якої можна використовувати:

1) акцентування уваги не на статевих, а на індивідуальних відмінностях людей: зокрема, пояснення поведінки, зовнішнього вигляду, особистісних якостей не статевими, а індивідуальними розбіжностями між людьми різних статей (наприклад, «Риболовлею захоплюються не тільки хлопчики, але й деякі дівчатка, як твоя подруга Ганнуся. А деякі хлопці не люблять ловити рибу, як їі брат Петро», «Полюбляють вишивати серветки і деякі дівчата, й деякі хлопці», «Хтось вважає, що тільки дівчата носять берети. Але їх носять і деякі хлопці, наприклад наш сусід Олег, а ще солдати-десантники»);

2) приклади існування в світі культурного різноманіття думок, норм та оцінок, в тому числі і відносно статі («В одній родині прибиранням займається тато, а мама керує автомобілем, в іншій - мама і тато працюють у поліції, а в третій - вчителями»; «В Ізраїлі і чоловіки, і жінки служать в армії; в Танзанії більшість чоловіків вдягнені у довгі спідниці, а жінки - в короткі»);

3) надання доступної інформації про сексизм і приклади викорінення дискримінації за ознакою статі в сучасному суспільстві (наприклад, «Раніше дівчата не мали можливості навчатися в університетах, займатися спортом і бути військовими, а хлопцям не дозволялося гратися ляльками і займатися рукоділлям») [1, с. 228].

Дотримання означеної моделі особистісно-оріснтованого виховання з урахуванням гендерного підходу сприятиме оптимізації процесу соціалізації хлопців. Адже такий підхід передбачає не тільки засвоєння існуючих зразків поведінки, але й уміння протиставляти їм свої нормативи та еталони; вимагає не просто підкорення прийнятним правилам, а дозволяє їх критично і творчо переосмислювати. Звільнення процесу виховання від впливу гендерних стереотипів дозволить хлопцям повноцінно розвиватися в тих напрямах, які будуть відповідати їхнім власним можливостям і прагненням.

Висновки. Можна стверджувати, що сенс соціального розвитку особистості майбутнього чоловіка проявляється перш за все в індивідуальному розвитку хлопчика. Тому сучасна соціалізація, яка передбачає відсутність гендерної диференціації та поляризації, має сприйматися батьками і педагогами як процес засвоєння хлопчиком нових гендерних ролей, що з'явилися у зв'язку з інтенсивними соціокультурними змінами.

Виховання хлопців з урахуванням гендерного підходу передбачає розширення можливостей вибору для них, а також відхід від такого розуміння мужності, яке не дозволяє їм виявляти повною мірою всі свої людські якості. Гендерний підхід перегукується з ідеями гуманізму, толерантності до різноманіття і світовою практикою ненасильницької педагогіки. Крім того, він цілком адекватний до реалій сучасної дійсності, тим змінам, які відбулися у суспільстві і детермінували закономірні зміни в житті чоловіків (не тільки кар'єра, але й сім'я). 


\section{Використана література:}

1. Бем С. Линзы гендера: Трансформация взглядов на проблему неравенства полов. Москва : РОММПЭН, 2004. 336 с.

2. Берн Ш. Гендерная психология. Законы мужского и женского поведения. Санкт-Петербург : Прайм-Еврознак, 2008.318 с.

3. Волынская Л. Б. Нерешенные психологические задачи детства в определении ценностно-смысловой структуры личности в дальнейшем. Мир психологии. 2004. № 1. С. 114-121.

4. Гончаров В. Л. Батько - особлива посада. Київ : Шкільний світ, 2010. 126 с.

5. Радина Н. К., Терешенкова Е. Ю. Возрастные и социокультурные аспекты гендерной социализации подростков. Bопросы психологии. 2006. № 5. С. 49-59.

6. Семёнова Л. Э., Семёнова В. Э. Воспитание современных девочек и мальчиков с позиций гендерного подхода. Гендерная психология: практикум. 2-е изд. / под. ред. И. С. Клециной. Санкт-Петербург : Питер, 2009. С. 211-227.

7. Штылёва Л. В. Фактор пола в образовании: гендерный подход и анализ. Москва : ПЕР СЭ, 2008. 316 с.

\section{References:}

1. Bem S. Lynzy hendera: Transformatsyia vzghliadov na problemu neravenstva polov. Moskva : ROMMPEN, 2004.336 s. [in Russian].

2. Bern Sh. Hendernaia psykholohyia. Zakony muzhskoho y zhenskoho povedenyia. Sankt-Peterburh : Praim-Evroznak, 2008. 318 s. [in Russian].

3. Volynskaia L. B. Nereshennye psykholohycheskye zadachy detstva v opredelenyy tsennostno-smyslovoi struktury lychnosty $\mathrm{v}$ dalneishem. Myr psykholohyy. 2004. № 1. S. 114-121 [in Russian].

4. Honcharov V. L. Batko - osoblyva posada. Kyiv : Shkilnyi svit, 2010. 126 s. [in Ukrainian].

5. Radyna N. K., Tereshenkova E. Iu. Vozrastnыe у sotsyokulturnыe aspektы hendernoi sotsyalyzatsyy podrostkov. Voprosы psykholohyy. 2006. № 5. S. 49-59 [in Ukrainian].

6. Semenova L. Э., Semenova V. Э. Vospytanye sovremennykh devochek y malchykov s pozytsyi hendernoho podkhoda. Hendernaia psykholohyia: praktykum. 2-e yzd. / pod. red. Y. S. Kletsynoi. Sankt-Peterburh : Pyter, 2009. S. 211-227 [in Russian].

7. Shtyleva L. V. Faktor pola v obrazovanyy: hendernyi podkhod y analyz. Moskva : PER SЭ, 2008. 316 s. [in Russian].

\section{Honcharenko O. V., Polianychko A. O. Gender education for boys and ways to optimize it}

The research is devoted to the problem of gender development of boys and necessity of his optimization. The authors analyze maintenance of gender socialization in the context of traditional (patriarchal) and modern (alternative) education. At present, in the context of studying the traditional approach to education, it has been determined that it is based on rigid gender differentiation of men and women and their strict hierarchical location.

This approach has been proven to emphasize the differences between men and women; focus on «special purpose» articles; consolidation of gender-stereotyped interests and preferences in boys; ignoring individuality and limiting freedom of choice; education of gender-schematized individuals. The basis for the personal development of boys is the image of a "real man", which is determined by the norms of status, firmness (physical, mental, emotional) and anti-femininity. It is stated that the existing norms, rules of conduct, attitudes towards cultural perceptions of the role, position and purpose of a man in society, which underlie the traditional upbringing of boys, lead to further difficulties in adulthood. Instead, the article substantiates the benefits of a gender-based model of upbringing, since it involves the development of boys beyond rigid gender precepts and stereotypes.

The authors argue that modern socialization implies a lack of gender differentiation, polarization, and is seen as a process of learning by boys new gender roles that have emerged in the face of intense socio-cultural change. In this model of education, it is identified that the role of families and educational institutions is increasing, which should become active subjects of positive changes in the process of gender development of male youth.

Key words: gender approach, gender and sex-role (traditional) education, gender norms, personality-oriented education.

\section{ДОСЛІДЖЕННЯ МОТИВАЦЙНО-ЦІННІСНОГО СКЛАДНИКА ГОТОВНОСТІ МАЙБУТНІХ УЧИТЕЛІВ ПОЧАТКОВОЇ ШКОЛИ ДО ОРГАНІЗАЦІї ДОЗВІЛЛЕВОЇ ДІЯЛЬНОСТІ ДІТЕЙ}

Проаналізовано критерії, методи та рівні визначення реального стану сформованості мотиваційно-ціннісного складника готовності майбутніх учителів початкової иколи до організачії дозвілля дітей. Метою статті є аналіз методики дослідження сформованості мотиваційно-иіннісного складника готовності майбутніх учителів початкової школи до організації дозвіллєвої діяльності учнів молодшого шкільного віку. Для досягнення мети використано методи дослідження: аналіз, синтез, узагальнення.

Визначено, щуо вчені по-різному трактують поняття готовності до професійної діяльності, визначають ії структуру та методи дослідження. Враховуючи специфіку педагогічної діяльності вчителя початкової школи, роль дозвілля у навчанні й вихованні дітей в умовах нової української школи, автором визначено готовність майбутнього вчителя початкової школи до організачії дозвіллєвої діяльності молодших школярів як сформоване інтегральне ціннісно-особистісне утворення, яке сприяє успішній комунікаиії у колективній діяльності на основі усвідомлених морально-етичних норм, переконань, включає здатність до постійного професійного самовдосконалення, самовираження задля виховання дітей як суб'єктів дозвіллєвої діяльності. 